\title{
Correction to: Past and Present of Latin American Jewry: A Conceptual Pathway
}

\author{
Judit Bokser Liwerant ${ }^{1}$ (D)
}

Published online: 12 September 2018

(c) Springer Nature B.V. 2018

\section{Correction to: Contemporary Jewry https://doi.org/10.1007/s12397-018-9268-3}

In the original publication of this article, the year 1994 has been mistakenly mentioned as 1995 in page 7 under the section When Biography and Scientific Research Meet in line 13.

The original article can be found online at https://doi.org/10.1007/s12397-018-9268-3.

Judit Bokser Liwerant

bokser@politicas.unam.mx

1 School of Political and Social Sciences, Universidad Nacional Autónoma de México, Mexico, Mexico 